\title{
Pedagogical Implication of Pesantren's Cultural Values In English Language Teaching
}

\author{
A H As Sabiq ${ }^{1}$, Suparjo ${ }^{2}$ \\ Institut Agama Islam Negeri (IAIN) Purwokerto, Kalipurwo 01/01 Kuwarasan Kebumen Jawa \\ Tengah, Indonesia ${ }^{1}$ \\ Institut Agama Islam Negeri (IAIN) Pangebatan 001/001 Karanglewas Purwokerto Jawa \\ Tengah, Indonesia ${ }^{2}$ \\ \{husein@iainpurwokerto.ac.id ${ }^{1}$, suparjohusain73@gmail.com²
}

\begin{abstract}
Learning is a social process in which culturally and historically situated participants engage in culturally-valued activities, using cultural tools. Multi-cultural backgrounds of the students and the cultural values of pesantren in MTs Al Iman Purworejo become the challenge for the teacher in delivering the course especially in ELT. The objectives of this research are: (1) to describe the pedagogical implication of Pesantren's cultural values in ELT in MTs Al Iman Purworejo; (2) to find out its effects in English learning. This research used an ethnography approach with qualitative data. The data sources in this research were teachers, students, and all written materials related to the research. There were some concluded findings, those are: (1) effective ICT utilization in improving students' motivation toward ELT; (2) contextualized learning materials based on the cultural context of students' environment and character-building; (3) good teacher-student relationship; (4) the implementation of cooperative learning; (5) and public speech practice.
\end{abstract}

Keywords: Pedagogical Competence, Pesantren Culture, ELT

\section{Introduction}

Understanding students' backgrounds are important to avoid misunderstanding of their abilities and teach English effectively, especially in a multi-cultural classroom[1], [2]. Learning is a kind of social process in which culturally and historically situated learners can engage in culturally-valued activities, using cultural tools. Besides, understanding the nature of the relationship between language and culture is central to the process of learning another language. In language learning classrooms, learners need to engage with the ways in which context affects what is communicated and how[3].

Both the learner's culture and the culture in which meaning is created or communicated have an influence on the ways in which possible meanings are understood. This context is not a single culture as both the target language and culture and the learner's own language and culture are simultaneously present and can be simultaneously engaged. Learning to communicate in an additional language involves developing an awareness of the ways in which culture interrelates with language whenever it is used[4].

Culture cannot be separated with the society. Acculturation is the result of cultural contact in which it establishes a new 'structure' of cultural society. Language has acculturation too with language contact among society. Thus, a new structure of language cannot be avoided and produce a different way to say something. That's why language will change over the 
time[5]. A person's mind is in a sense the centre of his identity, so if a person thinks in English in order to speak English, one might say that he has, in a way, almost taken on a English identity[6]. So, language teacher must consider the language change in order to give comprehensible input due to the social and language context.

Teachers should always have in mind when inserting culture in teaching and learning process about the need to raise their students' awareness of their own culture and 'the target culture' [7], [8], to cultivate a degree of intellectual objectivity essential in cross-cultural analysis[9]. Teachers are suggested to take the learners' socio-cultural background into consideration in choosing materials and pedagogical approaches for particular contexts of teaching. Meanwhile ignoring the students' norms and expectations is denying the learners' experiences[2], [10], and thus a lack of consideration of variations in cultures of learning can lead to frustration and subsequent failure in language classrooms[11]. Language mastery requires learners' mastery of the cultural contexts in which important social acts occur because it conveys warm feelings and solidarity among interlocutors[12], [13] and is categorized in the 'social' use of language. Language learners need to understand what native speakers mean when they use the language, even if they do not choose to replicate native speakers' behaviour [8].

The role of culture in teaching and learning of English as a foreign language can't be avoided while designing course for EFL students and in the classroom situations. The teachers should keep in mind the importance of culture and must have prior knowledge of the cultural knowledge of the chapter or lesson he is going to teach the students[13].

In order for communication to be successful, the teacher must consider the place of students' cultural environment in the teaching and learning process. By speaking the target language, someone can automatically align himself to engage in the culture of that language. Knowledge of cultures is important for facilitating communication with people[9]. Therefore learners of languages need to learn about and understand cultures. Understanding culture as practices with which people engage becomes centrally important. This means that in the language classroom it is not just a question of learners developing knowledge about another culture but of learners coming to understand themselves in relation to some other culture.

Based on the history, pesantren becomes a cultural heritage of Islam in Indonesia. It is not only an educational institution, but the culture of Islam itself. It is related to the basic pattern of Islamic civilization that glorifies education. Thus, education does not become a didactic process an sich, but the mode of being release from Islam [14]. The historicity of pesantren as mentioned above, has centered it nursery, experience, and all at once the dissemination of Islamic sciences li altafaqquh fî al-dîn (to study Islamic knowledge), one thing that is not found in public schools [15].

Pesantren, either from the root or tradition that is formed in it, basically it is indigenous. The word "Pesantren" itself comes from the Sanskrit word or Pali, "shastri", a term to see the scholar possesses the expertise of scriptures, the roots the word "santri" comes from the word "cantrik", the students in Dhoho Kediri country studying the religious sciences in a special hermitage [16]. Pesantren is not originated from the Arabic term, but from India. Pesantren, viewed in terms of form and the system, originated in India. Before the process of spreading Islam in Indonesia, the system has been used on a regular basis common for Hindu religious teachings at Java [17]. Pesantren culturally is an educational institution born of Indonesian culture, and historically contained not only the meaning of Islam, but also the meaning of Indonesian.

One of the schools under the auspices of pesantren is MTs Al Iman Purworejo. In designing the curriculum format, this school combines religious studies that have been taught 
in pesantren activities with common material matter. Al-Iman Islamic Boarding Purworejo also has students from various areas in this country, not only from local district of Purworejo, but also from many provinces even outside Java Island. MTs Al Iman is a junior high school that has its own characteristics. One of the differences of MTs Al Iman Purworejo from MTs or other junior high schools is in terms of curriculum. MTs Al Iman has a curriculum that combines national education curriculum and its own curriculum, plus extracurricular activities in schools, the students of MTs Al Iman also live in dormitories provided by the boarding school. Students also must comply with all existing regulations, not only rules of school but also rules of boarding school. Boys and girls live in separate dormitories, but each dormitory has rules and activities that are almost the same as had been arranged by the foundation boarding school.

In designing learning process, the teacher is demanded to design teaching and learning process correlated with the cultural environment of the students. The culture of boarding school should be included in the class due to the purpose of learning is appropriate with the purpose of boarding school. Multi-cultural backgrounds of the students and the culture of the boarding school environment in MTs Al Iman Purworejo become the challenge for the teacher in delivering the course especially in English classroom. The strategies and the materials that the teacher uses should be appropriate with students' culture. How the teacher deals with these various backgrounds becomes the point of this research.

From the background of the study above, the researchers limit the problems that are going to be discussed. This research focuses on how pedagogical implication of pesantren's cultural values is in English language teaching process in MTs Al Iman Purworejo and also how its implementation of culture can affect English learning. The objectives of this research are: (1) To describe the implementation of pesantren's cultural values in English language teaching and learning process in MTs Al Iman Purworejo; (2) To find out the effects of its implementation in English learning in MTs Al Iman Purworejo.

\section{Method}

This research used the ethnography approach. Related to this matter, hence this research was aimed to explore the form of pesantren's cultural values which were implemented in English learning process in MTs Al Iman Purworejo and also its influences in the learning process. Primary data sources in this research were the teacher and the students of MTs Al Iman Purworejo. The numbers of students MTs Al Iman Puworejo were actually more than 1000 students. Therefore, in determining the data sources, the researchers took four classes which consisted of 132 students. While the secondary data sources in this study, those were all written materials either in the form of books, reports, and documents related to the research.

In gathering the data in this research, it used some techniques and instruments. They were: (1) participatory observation, the instruments of participant observation were the form of observation sheet and field notes which were used to record what happen in the classroom and the environment in Pesantren. (2) The interview was used to find out the information of the preparation and implementation of pesantren culture by the teacher. (3) Documentation, the document as a source of data to be used in this research was the official and personal documents owned by the pesantren, MTs Al Iman Purworejo, and teachers.

Referring to the data analysis techniques, data analysis that were conducted on this research were domain analysis, taxonomic analysis, component analysis, and analysis of cultural themes. The domain analysis was used to obtain a general and comprehensive picture of the object of research or social situation under the study. The taxonomic analysis described 
the selected domains to be more detailed and to know the internal structure. The component analysis was used to seek the specific characteristics of each internal structure by contrasting elements. The analysis was done as a selected observation and interview with contrast question. The last one, that is the analysis of cultural themes was used to find relationships between domains, and how relationships with the whole.

\section{Result and Discussion}

\section{The character of Al-Iman Bulus Islamic Boarding School}

Al-Iman Islamic Boarding School has several characteristics that become its trademark and triggers the development of Islamic boarding schools. Among others are:

1) Flexibility for technological change

The management of Al Iman Islamic Boarding School is open-minded to receive globalization changes. Pesantren facilities and infrastructure are equipped with information and technological equipment. Sometimes, pesantren teachers teach students using technological tools, not always use classical systems. Easy to accept technological developments, Al Iman boarding schools tried not to miss renewable information. As the concept of pesantren Al Iman, "keeping the old traditions that are still good to be preserved and take the new things better to be implemented for improving the old become better and better".

\section{2) Group discussion}

Discussion activities in small groups or in large groups became the characteristic of $\mathrm{Al}$ Iman boarding students. They were accustomed to discuss in solving the problems. After completing the Maghrib prayer, the students went to their respective classes according to their level to attend religious scientific development activities. MTs students were required to recite the Qur'an with one of the seniors as the facilitator in a small group consist of 5-6 students. Small group discussion such as this made the learning process more conducive and directed. While MA (senior high school) students carried out whole class discussion activities related to fiqh or Arabic grammar. In this discussion activity, there was one group that gave a presentation in front of the class and the audience asked questions or objections, so that the atmosphere of the class was interesting scientific debate.

In addition to activities after the Maghrib prayer, the students in every 9 pm carried out joint learning activities which were sometimes accompanied by one of the seniors. The difference with the activities after Maghreb was that this joint learning activity focused more on learning the lessons they would learn in school in the next day. In this activity, the students also gathered in small groups. Students who have high intelligence often became peer tutors for others. This activity greatly supported the level of understanding of students in the school so that it was easy to receive further lessons.

3) Good relationship between the senior and junior

Most of the teachers in Al Iman formal school were the senior santri or alumni. They have recognized better the characteristic of the students. Besides, the students felt more enjoyable when they learn with the senior or alumni rather than with the teachers from the outside pesantren environment. This was because the intent interaction between the teacher and the students. It could be said that they would meet each other whether inside the school or outside 
the school (pesantren dormitory). So, the interaction between of them would occur every time students' lives and it made close each other.

\section{4) Character building and soft skill}

Beside the improvement of religious knowlegde, Al Iman activities schedule were also provided to improve students' characteristics and soft skill. For example, every Saturday night there is a public speaking activity which its pupose is to maintain students' talents and potentials skill. Sometimes, the students used bilingual speech (Bahasa Indonesia and English or Arabic) in deliver the lecture. Also, every Thursday night the students did activity called Simtud duroran that is reading the biography of Prophet Muhammad PBUH. This is done for planting love in students' hearts to the prophet.

\section{5) Politeness in communicating with the elder}

Another culture that the students usually do in their lives is respecting the older (senior/administrator/kyai). It was proved by their speech when making interaction with the older students. They would use boso kromo that is the formal Javanese language.

\section{Pedagogical Implementation of Pesantren Culture in English Classroom}

1) ICT utilization as leaning media

The teacher used the technological media in delivering the explanation. He is open-minded to receive renewable technological information in ELT. The teacher used ICT media such as slide projector, powerpoint presentation, video from youtube, and internet connection in teaching and learning process. The implementation of the ICT media as alternative media used in English class had two benefits.

First, the use of these media was effective in promoting students' motivation in learning English. The students' felt that they enjoyed learning in the class because they can refresh their mind by watching video or interesting pictures. They felt that they were not bored or sleepy anymore during the learning activities. They were challenged to observe, analyze, and communicate their ideas. Besides, they were motivated to be part in every learning activity. The use of ICT improves students' motivation and offers them different materials for the analysis and interpretation of both language and contexts [18]. The application of multimedia also makes use of print texts, film, and internet to enhance learners' linguistic knowledge[19].

Second, according to the teacher, the students seem to be more active in the class. They paid more attention to the teacher, the materials, and the learning activities. When they were asked to be volunteer, they scrambled to the first student who was pointed by the teacher to do the task in front of the class. When the teacher gave them some questions, there were not one or two students who raised their hands anymore, but there were more than five ten students wanted to answer the questions. They were enthusiastic to join the activities and do the task given. Moreover, they enjoyed working in collaborative groups that they were challenged to do the best than the other groups. The presence of ICT as learning media becomes the improvement of teaching styles and learners' learning. It can gain the students' engagement in the class.

The use of ICT makes the teachers to easily create positive atmosphere in the class[20], [21]. The students were asked about the media used by the teacher. They had positive attitudes towards the media and the enjoyed it. Students' feelings in engaging the learning process showed that the students had positive attitudes. They said:

Researcher : Do you like the media used by your teacher? 
Student : Yeah, I like it. The teacher usually uses pictures or shows the viedieo related to the materials.

\section{2) Cooperative learning}

In teaching and learning process, the teacher also used cooperative leaning. This method is basically implemented in the students' daily activities when they do group discussion after Maghrib pray and joint learning after 'isya. Group discussion became the students' habit in their dormitory, so the teacher took this strategy in enhancing the learning process in the class. When the teacher was asked about the influence of students learning habit in their dormitory, he answered:

"Yes, there is. The students are usually study in a group because that is studying together activity in their dorm after prayer isya."

The teacher realized that not all of the students having high enthusiasm in English classroom. Thus, the teacher played an important role in improving their motivation. Based on the teacher's statement, good teaching method and appropriate learning media would become the solution in enhancing the students' motivation and enthusiasm. Through ICT, the students can work cooperatively to do the task and learn with each other.

3) Contextualized learning material and character building

The teacher arranged the learning materials by himself in accordance with the context of the environment. Besides, the teacher inserted the islamic teaching such as Qur'anic verses related to the topic of material. The picture, for example, is contextualized with the pesantren culture and environment. The teacher delivered the materials in integration with the pesantren context. Also, the important point was inserting moral values in the material. The teacher said:

"I also tried to convey the material by combining material with Arabic, that is, material

that has similarities with Arabic. In addition, I also always try to relate the materials to the

students' daily lives related to social attitudes and character (akhlaq). "

The insertion of character values facilitates learning activities to build students' characters through character-based teaching materials[22]. Building students' characters through contextualized learning materials can be comprehended as the integration of massages and tools, also as the vehicle of culture and individual empowerment.

\section{4) Public speaking}

In every group discussion, the students were asked to communicate the result of the discussion in front of the class. Oral presentation practice was used by the teacher to improve the students' speaking skill. Beside improving students' speaking skill, the purpose of this activity was also to build students' characters as the activity that is usually followed in every Saturday night, e.i khitobah (public speech).

Public speech activity on Saturday night has driven the students to practice lecturing orally and trained them to deal with their confidence. Altough some students' were still anxiety to speak in front of the class, but generally they had high capability to improve their confidence and reduce anxiety. The role of teacher in this stage was really important on how he could drive the students to speak as much as they can in order to give opportunity to them to practice speaking more.

\section{5) Good relationship}

The teacher could manage the class properly in order to make a conducive atmosphere. This is because a good relationship between the teacher and the students where they will 
always meet each other not only in the classroom but also in the dormitory and pesantren activities. The tasks that the teacher gave are always done by the students. In some extent, the students sometimes felt that the teacher explained the material too fast, so the students could not reach the achievement. Also, there some students seem tend to focus on the media the teacher used not on the material given. It was proved by the students' statements when they were asked about the activity that the students liked more.

\section{Conclusion}

A dynamic relationship between language and culture is always at play. It is through an exploration of the interactions of language and culture that this awareness and the ability to act on it can be developed. Thus, inserting local culture in reference with students' environmental backgrounds should be considered by the teachers in order to build a meaningful learning process. It can be done through developing contextualized learning materials, designing cultural values learning activities, and building strong relationship between teachers and students. It can't be denied that learning other languages means learning the ways to engage in the target language culture and society. In Indonesian context with various culture of the society, the English teachers must be aware to keep maintaining local cultural values without affecting the goals of language learning and acquisition.

\section{References}

[1] N. Kojima, "The importance of understanding students' first classroom culture," Polyglossia, vol. 23, pp. 15-20, 2012.

[2] S. Dogancay-Aktuna, "Intercultural communication in English language teacher education," ELT J., vol. 59, no. 2, pp. 99-107, Apr. 2005.

[3] A. Scarino and A. J. Liddicoat, "Language, Culture and Learning," Teach. Learn. Lang. A Guid., 2009.

[4] A. J. Liddicoat and A. Scarino, Intercultural Language Teaching and Learning. 2013.

[5] S. M. Jafari, "Sepideh Moghaddas Jafari , PhD Student," vol. 2, no. 17, pp. 230-235, 2012.

[6] H. Syafri, "Expanding Instructional Model of Socio Affective Strategy for Speaking Skill in Islamic," Proc. ISELT FBS Univ. Negeri Padang, vol. 4, no. 1, pp. 363-376, 2016.

[7] Y. Wei, "Integrating Chinese culture into the EFL classroom," Sino-US English Teach., vol. 2, no. 7, pp. 55-58, 2005.

[8] M. Farnia and R. S. Raja Rozina, "Contrastive Pragmatic Study and Teaching Culture in English Language Classroom - A Case Study," no. February, pp. 242-257, 2015.

[9] W. Wen-Cheng, L. Chien-Hung, and C. Ying-Chien, "Cultural diversity and information and communication impacts on Language Learning," Int. Educ. Stud., 2011.

[10] C. Christie and S. McKay, "Teaching English as an International Language: Rethinking Goals and Approaches," TESOL Q., 2003.

[11] D. Li, “'It's Always More Difficult Than You Plan and Imagine': Teachers' Perceived Difficulties in Introducing the Communicative Approach in South Korea," TESOL Q., 1998.

[12] M. Byram, B. Gribkova, and H. Starkey, "Developing the intercultrual dimension in lanugage teaching A practical interoduction for teachers," 2002.

[13] R. U. Choudhury, "The Role of Culture in Teaching and Learning of English As a 
Foreign Language," Express, an Int. J. Multi Discip. Res., 2014.

[14] M. S. Zuhriy, "Budaya Pesantren dan Pendidikan Karakter pada Pondok Pesantren Salaf,” Walisongo J. Penelit. Sos. Keagamaan, vol. 19, no. 2, pp. 287-310, 2011.

[15] M. Burhanudin, "Nilai Humanisme Religius Syair Pesantren," J. Sastra Indones., 2017.

[16] H. A. Said, "MENEGUHKAN KEMBALI TRADISI PESANTREN DI NUSANTARA,” IBDA` J. Kaji. Islam dan Budaya, 2011.

[17] K. A. Steenbrink, "Academic Study of Indonesian Islam: A Biographical Account, 1970-2014,” Al-Jami'ah J. Islam. Stud., 2015.

[18] Arifah, "Study on the Use of Technology in ELT classroom : Teachers 'Perspective," no. December, 2014.

[19] M. R. Ahmadi, "Mohammad Reza Ahmadi 1*," Int. J. Res. English Educ., 2018.

[20] K. Dawson, C. Cavanaugh, and A. D. Ritzhaupt, "Florida's eett leveraging laptops initiative and its impact on teaching practices," J. Res. Technol. Educ., 2008.

[21] A. P. Gilakjani, "A detailed analysis over some important issues towards using computer technology into the EFL classrooms," Univers. J. Educ. Res., 2014.

[22] A. Sianipar, L. T., Setiawan, D., Rahman, "The development of character based on teaching materials according to the learning design experts through a contextual approach at grade V in SD Negeri 060841 Medan City, Indonesia.," Int. J. Educ. Learn. Dev., vol. 5, no. 10, pp. 19-36, 2017. 